\title{
Tingkat Kematangan Gonad dan Fekunditas Ikan Ingir-ingir (Mystus nigriceps, Valencieenes 1840) di Sungai Kampar Kiri Desa Mentulik Provinsi Riau
}

\section{(Gonad Maturity Level and Fekunditas Fish Ingir-ingir (Mystus nigriceps, Valencieenes 1840) in Kampar River Kiri Mentulik Village Riau Province)}

\author{
Syifa Ainun Walidaini ${ }^{*}$ Roza Elvyra \\ Jurusan Biologi, Fakultas Matematika dan Ilmu Pengetahuan Alam, Universitas Riau, Kampus Bina \\ Widya, Jl. HR Soebrantas Km 12.5, Panam, Pekanbaru 28293, Riau, Indonesia. \\ *Email korespondensi: syifaainun185@gmail.com
}

(Article History: Received Dec16, 2021; Revised Jan 20, 2022; Accepted Feb 2, 2022)

\begin{abstract}
ABSTRAK
Ikan Mystus nigriceps di Sungai Kampar Kiri Desa Mentulik merupakan ikan konsumsi masyarakat dan bernilai ekonomis sehingga sering dilakukan penangkapan yang menyebabkan penurunan populasi ikan ini di alam. Penelitian ini bertujuan untuk mengkaji tingkat kematangan gonad dan fekunditas ikan M. nigriceps. Sampel ikan diambil satu kali sebulan dari bulan Februari-Juli 2021. Parameter yang diukur meliputi tingkat kematangan gonad (TKG), indeks kematangan gonad (IKG), fekunditas dan diameter telur. Hasil penelitian menunjukkan bahwa tingkat kematangan gonad ikan jantan dan betina ditemukan pada tahap TKG I-IV yang didominasi oleh ikan betina paling banyak dijumpai pada bulan Juli. Indeks kematangan gonad ikan M. nigriceps betina lebih besar dibandingkan ikan jantan. Fekunditas ikan M. nigriceps berkisar antara 626-16.370 butir telur dengan diameter berkisar antara 0,43-0,75 $\mathrm{mm}$ dan memiliki pola pemijahan yang bersifat total spawner.
\end{abstract}

Kata Kunci: Mystus nigriceps; tingkat kematangan gonad; indeks kematangan gonad; fekunditas; diameter telur

\begin{abstract}
Mystus nigriceps fish in the Kampar Kiri River mentulik village is a fish consumption community and economical value so often fishing that causes a decline in the population of this fish in nature. The study aimed to examine the maturity level of gonads and the fecundity of M. nigriceps fish. Fish samples are taken once a month from February-July 2021. The parameters measured include gonad maturity level (TKG), gonad maturity index (IKG), fecundity and egg diameter. The results showed that the gonad maturity levels of male and female fish were found at the TKG I-IV stage which was dominated by the most common female fish in July. The gonad maturity index of female M. nigriceps fish is greater than that of male fish. The fecundity of M. nigriceps ranges from 626-16,370 eggs with diameters ranging from 0.43-0.75 $\mathrm{mm}$ and has a spawning pattern that is a total spawner.
\end{abstract}

Keywords: Mystus nigriceps; gonad maturity level; gonad maturity index; fecundity; egg diameter

\section{PENDAHULUAN}

Sungai Kampar merupakan salah satu sungai terbesar di Provinsi Riau dan termasuk ke dalam sungai rawa banjiran. Rawa banjiran (floodplain) merupakan suatu ekosistem yang dicirikan oleh fluktuasi air yang terjadi antara musim kemarau dan penghujan yang bervariasi sepanjang tahun (Welcomme 2001). Beragamnya habitat di sungai rawa banjiran dimanfaatkan ikan untuk menunjang proses kehidupannya seperti pemijahan, pengasuhan anak (Ribeiro et al. 2004), mencari makan dan habitat ikan-ikan dewasa selama siklus hidupnya (Borcherding et al. 2002). Sungai Kampar Kiri Desa Mentulik memiliki perairan berwarna kuning kecoklatan, pada bagian pinggiran sungainya masih banyak ditumbuhi berbagai jenis pepohonan dan terdapat penangkaran ikan (Elvyra 2000). Sungai Kampar Kiri Desa Mentulik memiliki berbagai macam jenis ikan-ikan khas rawa banjiran, salah satunya adalah ikan ingir-ingir.

Ikan ingir-ingir merupakan ikan konsumsi yang bernilai ekonomis dan cukup 
diminati oleh masyarakat (Purba et al. 2019). Namun hasil tangkapan ikan ini di alam mulai mengalami penurunan. Pada tahun 2007 hingga 2017 hasil tangkapan ikan ingir-ingir menurun dari 11.853 ton per tahun menjadi 3.772 ton per tahun (KKP 2018). Hal ini disebabkan oleh aktivitas penangkapan yang dilakukan secara terus menerus (Sari et al. 2019) dan mulai terganggunya habitat hidup ikan akibat penambangan emas yang membawa limbah ke perairan sehingga mengubah kondisi ekologi perairan dan organisme yang ada di dalamnya (Stoddard et al. 2003).

Penangkapan yang dilakukan secara terus menerus dikhawatirkan dapat membuat populasi ikan ingir-ingir di Sungai Kampar Kiri Desa Mentulik dapat mengalami penurunan jika tidak dilakukan upaya pelestarian. Salah satu upaya yang dapat dilakukan adalah dengan melakukan kegiatan budidaya. Dalam mengembangkan ikan ingir-ingir sebagai komoditas budidaya, maka perlu diketahui kapan waktu pemijahan ikan dengan mempelajari tingkat kematangan gonad ikan. Hal ini dilakukan supaya dapat diketahui kapan saja waktu yang efektif untuk dilakukan penangkapan agar populasi ikan ingir-ingir dapat terjaga. Penelitian ini sudah pernah dilakukan di Sungai Kabupaten Kampar, di Oxbow Pinang Luar Desa Buluh Cina Kecamatan Siak Hulu dan di Sungai Tapung Kiri Desa Pantai Cermin Kecamatan Tapung Kabupaten Kampar. Namun, untuk di Desa Mentulik Sungai Kampar Kiri belum pernah dilakukan sehingga informasi dan data aspek biologinya masih kurang serta belum adanya kegiatan pombudidayaan terhadap ikan ini. Oleh sebab itu, penelitian ini bertujuan untuk mengetahui mengkaji tingkat kematangan gonad, indeks kematangan gonad, fekunditas, serta diameter telur ikan.

\section{METODE}

\section{Waktu dan Tempat}

Penelitian dilakukan pada bulan Februari 2021 sampai Juli 2021. Pengambilan sampel dilakukan di Sungai Kampar Kiri Desa Mentulik, Provinsi Riau.
Pengamatan dan pengukuran sampel dilakukan di Laboratorium Zoologi Jurusan Biologi Fakultas Matematika dan Ilmu Pengetahuan Alam Universitas Riau.

\section{Alat dan Bahan}

Alat yang digunakan dalam penelitian ini adalah $\mathrm{DO}$ meter, $\mathrm{pH}$ meter, termometer, secchi disk, alat bedah, botol film ukuran 30 cc, kertas milimeter block F4, neraca digital, cawan petri, kaca objek, cover glass, beaker glass ukuran $250 \mathrm{ml}$, hand tally counter, mikrometer okuler dan Mikroskop Binokuler Olympus CX-23. Bahan yang digunakan dalam penelitian ini adalah sampel ikan ingir-ingir ( $M$. nigriceps) yang diperoleh dari hasil tangkapan nelayan dan alkohol $70 \%$.

\section{Cara Kerja}

\section{Tingkat Kematangan Gonad}

Penentuan tingkat kematangan gonad (TKG) mengacu pada Ambarwati (2008) dilakukan dengan tahapan sampel ikan dibedah kemudian gonad ikan ditimbang. TKG ikan ditentukan secara morfologi berdasarkan modifikasi Cassie (Effendie 1997). Gonad dimasukkan ke dalam botol film berisi alkohol $70 \%$.

\section{Indeks Kematangan Gonad}

Indeks kematangan gonad (IKG) secara temporal dapat mengindikasikan musim pemijahan. Indeks kematangan gonad dihitung dengan menggunakan rumus sebagai berikut (Sari et al. 2014):

$$
\text { IKG }=\frac{B g}{B t} \times 100
$$

Keterangan :

$$
\begin{aligned}
& \mathrm{IKG}=\text { Indeks Kematangan Gonad }(\%) \\
& \mathrm{Bg}=\text { berat } \operatorname{gonad}(\mathrm{g}) \\
& \mathrm{Bt}=\text { berat tubuh }(\mathrm{g}) .
\end{aligned}
$$

\section{Fekunditas dan Diameter Telur}

Penentuan fekunditas dan diameter telur dilakukan pada ikan yang telah mencapai TKG IV dan V. Cara mendapatkan telur mengacu pada Harianti (2013) dengan cara gonad ikan ditimbang (berat total). Gonad dipisahkan kanan dan kiri diambil sebagian 
(anterior, tengah dan posterior) kemudian ditimbang. Subbagian gonad dimasukkan ke dalam botol sampel berisi alkohol $70 \%$. Telur dikeluarkan dan diukur dengan cara menderetkan telur di atas object glass. Kemudian diamati dengan Mikroskop Binokuler Olympus CX-23 dengan perbesaran 10 kali yang dilengkapi dengan mikrometer okuler. Diameter telur dari 6 sub sampel ovari tersebut diukur. Hasil dari pengukuran diameter telur dikonversikan ke dalam milimeter $(\mathrm{mm})$. Fekunditas ikan dapat dianalisis dengan menggunakan rumus Effendie (2002) yaitu:

$\mathrm{F}=\frac{\boldsymbol{W}}{\boldsymbol{w}} \times \mathbf{n}$

Keterangan :

$\mathrm{F} \quad=$ nilai fekunditas (butir)

$$
\begin{array}{ll}
\mathrm{W} & =\text { berat } \operatorname{gonad}(\mathrm{g}) \\
\mathrm{W} & =\text { berat cuplikan }(\mathrm{g}) \\
\mathrm{n} & =\text { jumlah telur dalam cuplikan (butir) }
\end{array}
$$

\section{HASIL DAN PEMBAHASAN}

Ikan $M$. nigriceps yang tertangkap sebanyak 116 ekor selama 4 bulan penelitian pada tingkat kematangan gonad I-IV yang bervariasi setiap bulannya. Jumlah ikan jantan dan betina pada setiap TKG dapat dilihat pada Gambar 1, TKG IV ditemukan setiap bulan pada ikan $M$. nigriceps betina sedangkan pada ikan jantan tidak ditemukan pada bulan Juni. Hal ini diduga disebabkan karena pada saat penangkapan, bukan merupakan spawning ground, sehingga ikan $M$. nigriceps sudah ke tempat pemijahan.

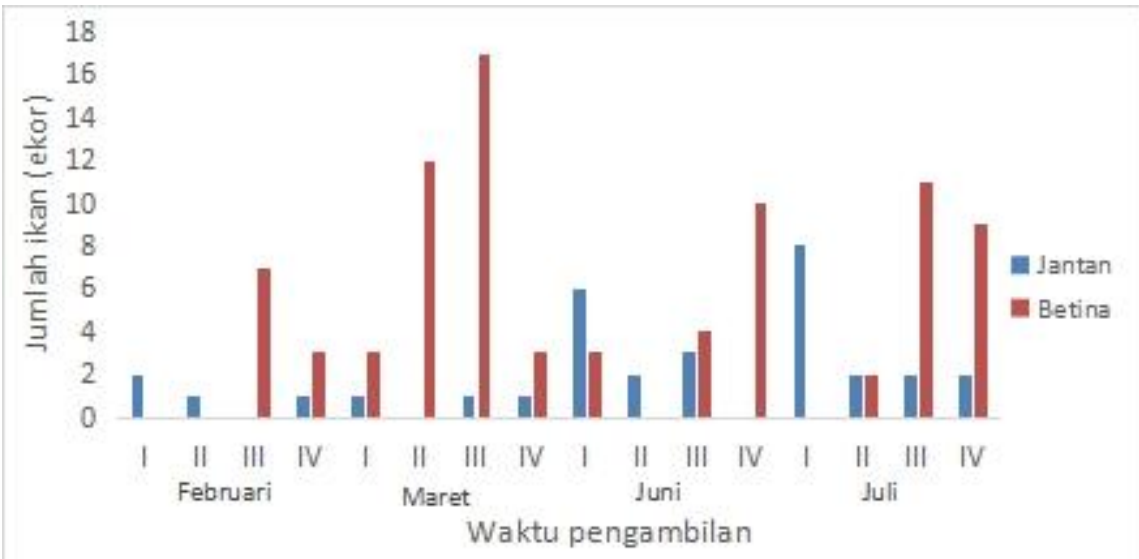

Gambar 1. Jumlah ikan M. nigriceps jantan dan betina berdasarkan tingkat kematangan gonad (TKG) selama penelitian

Hasil penelitian menunjukkan TKG V pada ikan $M$. nigriceps jantan maupun ikan betina tidak ditemukan selama penelitian. Hal ini karena ikan $M$. nigriceps yang masih dalam tahap menuju pemijahan dan belum memasuki fase pasca pemijahan (TKG V). Kondisi ini juga dapat disebabkan karena singkatnya periode waktu dari memijah ikan menuju ke pembentukan kembali sel-sel telur sehingga ikan pada TKG $\mathrm{V}$ tidak ditemukan pada penelitian ini (Rohardjo et al. 2007).

TKG IV paling banyak ditemukan pada bulan Juli. Kondisi tersebut dapat diduga bahwa puncak pemijahan ikan $M$. nigriceps terjadi setelah bulan tersebut yaitu kisaran bulan Juni-September. Hal ini juga berhubungan dengan kondisi lingkungan seperti curah hujan (Burhanuddin 2010). Pada bulan Juli tersebut, air sungai sedang berada dalam keadaan air tinggi seiring dengan masuknya musim hujan. Pada saat permukaan air naik, ketersediaan makanan di sungai akan melimpah sehingga akan merangsang ikanikan untuk mempercepat pematangan gonadnya. 
Tabel 1. Ukuran panjang total (PT) dan berat tubuh (BT) ikan M. nigriceps pada setiap TKG selama penelitian

\begin{tabular}{ccccccc}
\hline \multirow{2}{*}{$\begin{array}{c}\text { Jenis } \\
\text { Kelamin }\end{array}$} & \multirow{2}{*}{ TKG } & $\mathrm{n}$ & \multicolumn{2}{c}{ PT $(\mathrm{cm})$} & \multicolumn{2}{c}{ BT $(\mathrm{g})$} \\
\cline { 4 - 7 } & & & Kisaran & Rerata & Kisaran & Rerata \\
\hline \multirow{4}{*}{ Jantan } & I & 17 & $11,4-16$ & 14,25 & $8,75-21,69$ & 16,52 \\
& II & 5 & $12,5-16$ & 13,98 & $12,11-19,96$ & 15,25 \\
& III & 6 & $14,6-16,2$ & 15,72 & $20,15-34,71$ & 24,77 \\
& IV & 4 & $14,3-16,3$ & 15,48 & $18,65-23,58$ & 20,66 \\
\hline \multirow{5}{*}{ Betina } & I & 6 & $13-16,2$ & 13,77 & $12,47-21,92$ & 16,46 \\
& II & 14 & $13,3-16,2$ & 14,91 & $11,26-24,30$ & 18,48 \\
& III & 39 & $11,4-18,5$ & 15,03 & $7,62-36,22$ & 20,99 \\
& IV & 25 & $12,8-18,5$ & 15,07 & $13,37-36,84$ & 20,66 \\
\hline
\end{tabular}

Berdasarkan kisaran panjang dan berat tubuh pada ikan $M$. nigriceps jantan dan betina di setiap TKG (Tabel 1) menunjukkan hasil bahwa pada ukuran yang sama rata-rata ikan $M$. nigriceps jantan lebih cepat matang gonad dibandingkan ikan betina. Namun ada juga ikan jantan dan betina yang matang gonad dibandingkan ikan betina. Namun ada juga ikan jantan dan betina yang matang gonad secara bersamaan (Rohardjo et al. 2007).

Perbedaan kemampuan matang gonad ini disebabkan oleh perbedaan pertumbuhan gonad antara ikan jantan dan betina. Biasanya ikan jantan lebih cepat matang gonad dibandingkan ikan betina karena ikan betina membutuhkan waktu yang lebih banyak untuk perkembangan gonadnya supaya telur yang dihasilkan dalam keadaan baik (Rahardjo et al. 2007).

Pada umumnya berat tubuh ikan akan bertambah seiring dengan meningkatnya perkembangan gonad. Namun pada penelitian ini didapatkan rata-rata ikan pada TKG III yang lebih dominan panjang dan berat tubuhnya dibandingkan ikan pada TKG IV dikarenakan ikan pada TKG IV ditemukan memiliki ukuran yang cenderung lebih kecil, sedangkan ikan pada TKG III ukurannya cenderung lebih besar. Hal ini dapat disebabkan karena ikan pada TKG IV lebih sering ditangkap untuk dikonsumsi sehingga pertumbuhannya menuju kedewasaan menjadi terhambat. Menurut Barbieri et al. (2015) ukuran ikan matang gonad pada ukuran yang lebih kecil merupakan taktik reproduksi ikan untuk memulihkan keseimbangan populasinya yang disebabkan oleh perubahan kondisi, faktor abiotik dan penangkapan berlebih.

Nilai rataan IKG pada ikan $M$. nigriceps betina lebih besar dibandingkan ikan jantan (Gambar 2). Hal ini disebabkan karena pertambahan bobot ovarium pada ikan betina lebih besar dibandingkan bobot testes pada ikan jantan sehingga rata-rata nilai IKG ikan betina lebih tinggi. Artinya, pengaruh perkembangan gonad terhadap bobot gonad pada ikan betina lebih signifikan daripada ikan jantan. Menurut Nataliska et al. (2019), perbedaan nilai IKG ikan jantan dan betina dikarenakan di dalam ovari terjadi proses pembentukan kuning telur sehingga volume ovari lebih besar dibandingkan testes dan menyebabkan berat gonad ikan betina mengalami peningkatan yang lebih besar dari ikan jantan. 


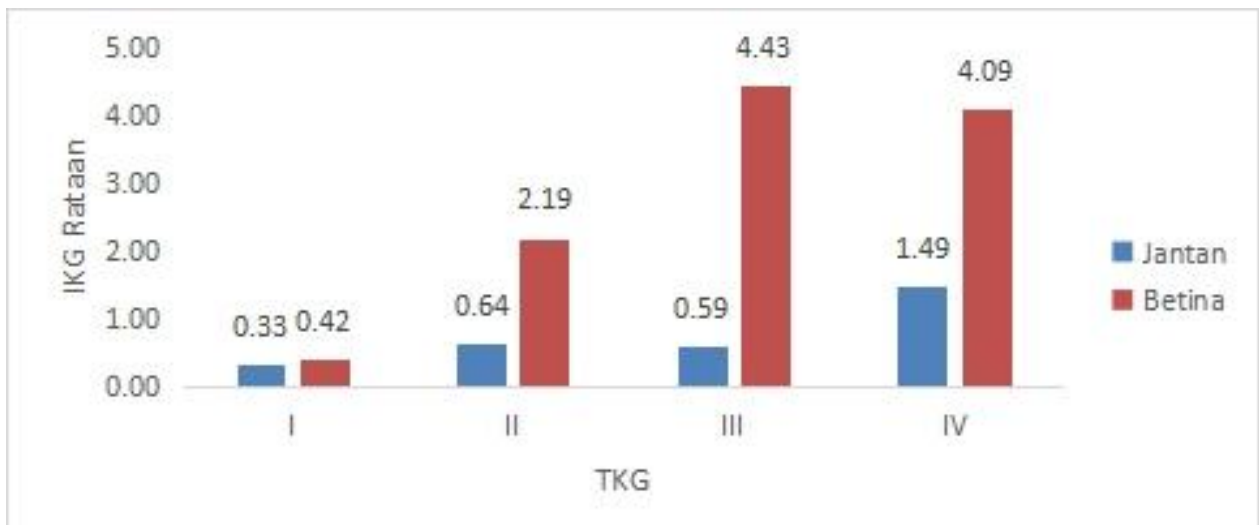

Gambar 2. Indeks kematangan gonad (IKG) ikan M. nigriceps jantan dan betina berdasarkan tingkat kematangan gonad selama penelitian

Fekunditas ikan $M$. nigriceps diperoleh sebanyak 25 sampel gonad yang sudah matang. Jumlah telur yang diperoleh berkisar antara 626-16.370 butir telur pada kisaran berat tubuh 13,37-36,84 g. Jumlah telur terendah ditemukan pada ikan dengan panjang total tubuh $16 \mathrm{~cm}$ dan bobot tubuh $21,51 \mathrm{~g}$ sebanyak 626 butir telur. Sedangkan jumlah telur tertinggi ditemukan pada ikan dengan panjang total tubuh $14,2 \mathrm{~cm}$ dan bobot tubuh 26,46 g sebanyak 16.370 butir telur. Ikan dengan bobot tubuh yang besar tidak selalu memiliki fekunditas yang banyak. Hal ini karena bobot lambung yang besar sedangkan bobot gonadnya kecil sehingga fekunditas pada bobot tersebut menjadi berkurang (Harianti 2013). Menurut Banik et al. (2012), nilai fekunditas yang bervariasi pada spesies ikan dapat disebabkan oleh faktor lingkungan yang berbeda-beda seperti suhu perairan, sumber makanan, kelimpahan makanan, dan perbedaan spesies.

Diameter telur ikan $M$. nigriceps betina yang diamati berjumlah 25 ekor. Ukuran diameter telur ikan $M$. nigriceps pada setiap bagian sub sampel yang diamati pada bagian anterior, tengah dan posterior rata-rata memiliki ukuran yang sama. Diameter telur yang diamati memiliki ukuran yang bervariasi berkisar antara 0,43-0,75 $\mathrm{mm}$. Menurut Safrina (2007) ukuran telur pada TKG IV yang bervariasi terjadi karena adanya pembentukan butir telur (yolk) yang berbeda-beda sehingga ukuran diameter telur menjadi berbeda.

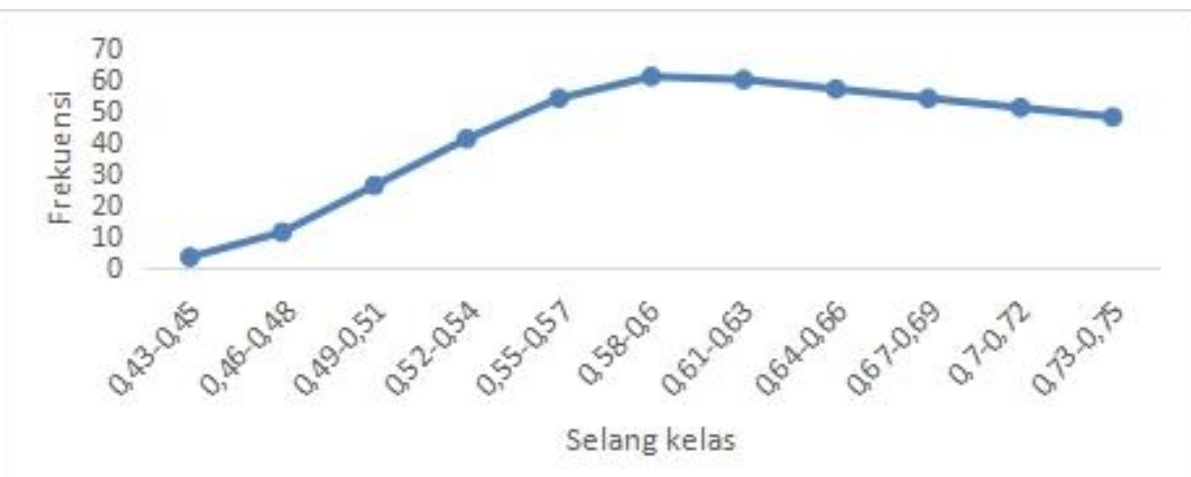

Gambar 3. Sebaran diameter telur ikan M. nigriceps pada tingkat kematangan gonad IV

Tipe pemijahan ikan dapat dilihat dari pola penyebaran diameter telur dalam gonad yang sudah matang, yaitu dengan melihat modus penyebarannya (Gambar 3). Pola pemijahan ikan $M$. nigriceps berdasarkan sebaran diameter telur yang diperoleh bersifat pemijahan serentak (total spawner). Tipe pemijahan total spawner yaitu 
pemijahan ikan yang dilakukan dengan mengeluarkan telur masak dari ovarium secara keseluruhan pada suatu waktu pemijahan (siklus reproduksi) dan akan dapat melakukan pemijahan kembali pada musim pemijahan berikutnya.

Namun, berdasarkan grafik tingkatan kematangan gonad setiap bulan (Gambar 1) beberapa ikan $M$. nigriceps pada TKG IV ditemukan juga dibulan Februari dan Maret meskipun dalam jumlah yang sangat rendah. Hal ini dapat berhubungan dengan strategi reproduksi ikan tersebut sebagai adaptasi ikan terhadap kondisi lingkungan dan aktifitas penangkapan sehingga masih dijumpai beberapa ikan matang gonad di bukan pada musim pemijahannya (Fadillah 2018).

\section{KESIMPULAN}

Tingkat kematangan gonad (TKG) ikan $M$. nigriceps jantan dan betina ditemukan pada TKG I-IV. Indeks kematangan gonad (IKG) ikan $M$. nigriceps jantan berkisar antara 0,11-2,52 \% dan betina berkisar antara 0,22-20,60 \%. Fekunditas ikan $M$. nigriceps berkisar antara 626-16.370 butir telur. Diameter telur ikan $M$. nigriceps berkisar 0,43-0,75 $\mathrm{mm}$ dengan pola pemijahan ikan yaitu total spawner. Berdasarkan data tersebut maka dapat dilakukan usaha pengelolaan dengan mengurangi aktivitas penangkapan pada saat ikan sedang melakukan pemijahan dan menggunakan alat tangkap yang selektif untuk penangkapan. Data fekunditas ikan juga dapat digunakan untuk mengetahui musim pemijahan dan ukuran ikan yang produktif untuk menghasilkan keturunan sebagai data masukan dalam pemilihan bibit ikan untuk kegiatan budidaya.

\section{UCAPAN TERIMA KASIH}

Penelitian ini dibiayai oleh Hibah Penelitian Mahasiswa S-1 Universitas Riau Advanced Knowledge and Skills for Sustaiinable Growth in Indonesia (AKSI) Project Asian Development Bank (ADB) Tahun 2021.

\section{DAFTAR PUSTAKA}

Ambarwati DVS (2008) Studi Biologi Reproduksi Ikan Layur (Superfamili Trichiuroidea) Di Perairan Palabuhanratu, Kabupaten Sukabumi, Jawa Barat. Skripsi. Program Sarjana Institut Pertanian Bogor. Bogor

Banik S, Goswami P, Acharjee T, Malla S (2012) Ompok pabda (Hamilton Buchanan, 1822): an Endangered Catfish of Tripura, India: Reproductive Physiology Related to Freshwater Lotic Environment. Journal of Environment 1(2): 45-55

Boercherding J, Bauerfeld M, Hintzen D, Neumann D (2002) Lateral migrations of

fishes between floodplain lakes and their drainage channels at the Lower Rhine: diel and seasonal aspects. Journal of Fish Biology 61: 1154-1170

Burhanuddin AI (2010) Ikhtiologi, Ikan dan Aspek Kehidupan. PT. Yayasan Citra Emulsi, Makassar

Effendie MI (1997) Metode Biologi Perikanan. Yayasan Dewi Sri, Bogor

Effendie MI (2002) Biologi Perikanan. Yayasan Pustaka Nusatama, Yogyakarta

Elvyra R (2000) Beberapa Aspek Ekologi Ikan Lais Kryptopterus limpok (Blkr). Di sungai Kampar Kiri, Riau. Tesis. Program Pasca Sarjana, Universitas Andalas. Padang

Fadillah PN (2018) Analisis Fekunditas dan Diameter Telur Ikan Lencam (Lethrinus lentjan Lacepede, 1802) Didaratkan di Tempat Pelelangan Ikan (TPI) Beba, Kecamatan Galesong Utara, Kabupaten Takalar. Skripsi. Program Sarjana Universitas Hasanuddin. Surabaya

Harianti (2013) Fecundity and Egg Diameter of Stripped snakehead (Channa striata bloch, 1793) in Tempe Lake, Wajo. Saintek Perikanan: Indonesian Journal of Fisheries Science and Technology 8(2): 18-24 
Kementrian Kelautan dan Perikanan (2018) Potensi Usaha dan Peluang Investasi Kelautan dan Perikanan Provinsi Riau. Direktorat Jenderal Penguatan Daya Saing Produk Kelautan dan Perikanan, Jakarta

Nataliska, Efizon D, Efawani (2019) Biologi Reproduksi Ikan Ingir-ingir (Mystus nigriceps) di Sungai Tarai Kabupaten Kampar Provinsi Riau. Jurnal Online Mahasiswa FAPERIKA 1-13

Purba WSO, Efizon D, Efawani (2019) Morfometrik, Meristik, dan Pola Pertumbuhan Ikan Ingir-ingir (Mystus nigriceps Valenciannes) di Sungai Tarai Desa Tarai Bangun Kecamatan Tambang Kabupaten Kampar Provinsi Riau. Jurnal Online Mahasiswa FAPERIKA 1-9

Rahardjo MF, Simanjuntak CPH (2007) Aspek Reproduksi Ikan Teet, Johnius belangerii Cuvier (Pisces: Scianidae) di Perairan Pantai Mayangan, Jawa Barat. J. Fish, Sci 9(2): 200-207

Ribeiro F, Crain PK, Moyle PB (2004) Variation in Condition Factor and Growth in Young-Ofyear Fishes in Floodplain and Riverine Habitats of the
Cosumnes River, California. Hydrobiologia 527: 77-84.

Safrina N (2007) Aspek Biologi Reproduksi Ikan Barau (Hampala macrolepidota c. v) di Waduk PLTA Koto Panjang, Riau Skripsi. Program Sarjana Universitas Riau. Riau

Sari KS, Putra RM, Efawani (2019) Biologi Reproduksi Ikan Mystus nigriceps C.V, 1840 di Sungai Tapung Kiri Desa Pantai Cermin, Kecamatan Tapung, Kabupaten Kampar, Provinsi Riau. Jurnal Online Mahasiswa FAPERIKA $1-10$

Sari RM, Elvyra R, Yusfiati (2014) Biologi Reproduksi Ikan Lais Panjang Lampung (Kryptopterus apogon) di Sungai Kampar Kiri dan Sungai Tapung, Provinsi Riau. Jurnal Online Mahasiswa FMIPA 1(2): 372-383

Stoddard AJB, Harcum JT, Simpson JR, Pagenkop K, Bastian (2003) Municipal Wastewater Treatment: Evaluating Improvements in National Water Quality. Published by John Wiley and Sons, Inc

Welcomme RL (2001) River Fisheries. FAO Fisheries Technical, Rome 